\title{
Mechanisms involved in the nutritional regulation of mRNA translation: features of the avian model
}

\author{
Sophie Tesseraud*, Mourad Abbas, Sophie Duchene, Karine Bigot, Pascal Vaudin and Joëlle Dupont \\ Institut National de la Recherche Agronomique, Tours, 37380 Nouzilly, France
}

\begin{abstract}
Insulin and amino acids are key factors in regulating protein synthesis. The mechanisms of their action have been widely studied for several years. The insulin signal is mediated by the activation of intracellular kinases such as phosphatidylinositol-3'kinase and the mammalian target of rapamycin (mTOR), affecting the phosphorylation of some major effectors involved in the regulation of translation initiation, i.e. p70 S6 kinase (p70S6K) and the translational repressor eukaryotic initiation factor $4 \mathrm{E}$ binding protein (4E-BP1). The amino acid-induced signalling cascade also originates from mTOR and promotes p70S6K and 4E-BP1 activation. However, the mechanisms of regulation are complex and little understood, especially in vivo. Elucidating these mechanisms is important for both fundamental physiology and nutritional applications, i.e. better control of the use of nutrients and optimisation of dietary amino acid supplies in various physiological and physiopathological situations. In comparative physiology, the chicken is an interesting model to gain better understanding of the nutritional regulation of mRNA translation because of the very high rates of muscle growth and protein synthesis, and the unusual features compared with mammals. In the present review we provide an overview of the roles of insulin and amino acids as regulators of protein synthesis in both mammals and avian species.
\end{abstract}

Insulin: Amino acids: Signalling: Chickens: Mammals: Protein translation

\section{Introduction}

Protein synthesis is achieved via a succession of steps, the majority of which are currently fully identified. It is controlled by physiological (for example, growth, lactation), genetic and environmental factors (for example, ambient temperature, nutritional factors). The nutritional regulation of protein synthesis involves the nutrients themselves and also hormones. For example, insulin and amino acids, whose plasma concentrations increase after food intake (i.e. in the postprandial period), are recognised as key factors in such regulation.

The regulation of protein synthesis by insulin has been the subject of many studies. It appears clearly in vitro (incubated muscles, cell cultures) that insulin stimulates protein synthesis (Kimball et al. 1994; Grizard et al. 1999). The phenomenon is a dose-dependent stimulation, reaching a maximum hormone effect for supraphysiological concentrations (about $1.75 \mathrm{nM}-$ insulin, i.e. double the postprandial level, as observed in incubated rat muscle by Dardevet et al. (1994)). A positive effect of insulin on protein synthesis is more difficult to demonstrate in vivo. It has been reported in studies carried out in very young animals in the post-absorptive state and in those with decreased protein synthesis, i.e. diabetes, injection of an anti-insulin antibody or with a treatment blocking insulin secretion, such as diazoxide or somatostatin (Sinaud et al. 1999; Kimball et al. 2002; O'Connor et al. 2003a). Amino acids clearly stimulate protein synthesis both in vitro and in vivo (Balage et al. 2001; Kimball \& Jefferson, 2002, 2005; Yoshizawa, 2004). Postprandial stimulation of protein synthesis by amino acids or insulin is associated with an increase in translational efficiency, in particular with stimulation of the initiation phase. Amino acids are thus mediators of metabolic pathways; they act as signal molecules and directly activate signalling pathways leading to the stimulation of protein synthesis.

Because of its fast growth rate, the chicken is an interesting species for the study of the nutritional regulation

\footnotetext{
Abbreviations: Akt, protein kinase B; 4E-BP1, eukaryotic initiation factor 4E binding protein; eIF, eukaryotic initiation factor; ERK, extracellular signal-regulated protein kinase; IR, insulin receptor; IRS, insulin receptor substrate; MAPK, mitogen-activated protein kinase; mTOR, mammalian target of rapamycin; PDK, phosphoinositide-dependent kinase; PH, pleckstrin homology; PI3K, phosphatidylinositol-3'kinase; PIP3, phosphatidylinositol-3',4,5-triphosphate; PKB, protein kinase B; PKC, protein kinase C; p70S6K, $70 \mathrm{kDa}$ ribosomal protein S6 kinase; PTEN, phosphatase and tensin homologue; raptor, regulatory associated protein of mammalian target of rapamycin; rictor, rapamycin-insensitive companion of mammalian target of rapamycin; SH2, Src homology 2; Shc, Src homology and collagen protein; TSC, tuberous sclerosis complex.
}

* Corresponding author: Dr Sophie Tesseraud, fax +3324742 77 78, email tesserau@tours.inra.fr 
of muscle growth and protein synthesis in general. It currently reaches the weight of $2.5 \mathrm{~kg}$ in less than 6 weeks and presents particularly high rates of muscle protein synthesis (Muramatsu, 1990; Tesseraud, 1995). In this species, the role of insulin is probably similar to that described in mammals. For example, in vitro studies in avian species have demonstrated the stimulation of protein synthesis by insulin (at low concentrations) in embryo fibroblasts, heart cells, and myoblasts or myotubes from skeletal muscles (for a review, see Simon, 1989). However, the chicken exhibits several remarkable physiological characteristics compared with mammals: chronic hyperglycaemia ( $2 \mathrm{~g} / \mathrm{l})$; resistance to diabetogenous drugs; relative resistance to exogenous insulin of mammalian origin (Simon, 1989; Taouis et al. 1993; Akiba et al. 1999). There are also unusual features concerning the transduction of the insulin signal. For example, the function of the insulin receptor (IR) in chicken muscle appears different from that classically described in mammals, and other signalling pathways may be involved in signal transduction.

The goal of the present review is to gather the available information on the mechanisms involved in the nutritional regulation of mRNA translation, with a particular focus on the effects of insulin and amino acids. This is mainly based on the data obtained in mammals, while emphasising the characteristics and values of the avian model.

\section{Key steps of mRNA translation}

The translation of mRNA into proteins in the cytoplasm is divided into three main phases. These are: (1) the initiation phase, corresponding to the sequential fixing of the $40 \mathrm{~S}$ and $60 \mathrm{~S}$ ribosomal subunits on the mRNA molecule (Fig. 1); (2) the elongation phase, during which amino acids, activated in the form of aminoacyl tRNA, are built into polypeptides according to the mRNA sequence; (3) the termination phase, during which the complete polypeptide is released into the cytoplasm where it undergoes post-translational modifications. Specific proteins called eukaryotic initiation factors (eIF), eukaryotic elongation factors and releasing factors are key components of each of these three phases. Research during the last 10 years has made it possible to specify the structure, function and regulation of these factors in physiological conditions and to identify untranslated mRNA sequences located in $5^{\prime}$ and $3^{\prime}$ involved in the specific selection of mRNA to translate. Each of the three phases of protein synthesis is controlled. However, most of these known regulation mechanisms are related to the initiation phase, defined as a limiting step of protein synthesis (Pain, 1996).

Some major proteins involved in the control of the initiation of mRNA translation have been identified in mammals. They include: (1) eIF2 and eIF2B eukaryotic

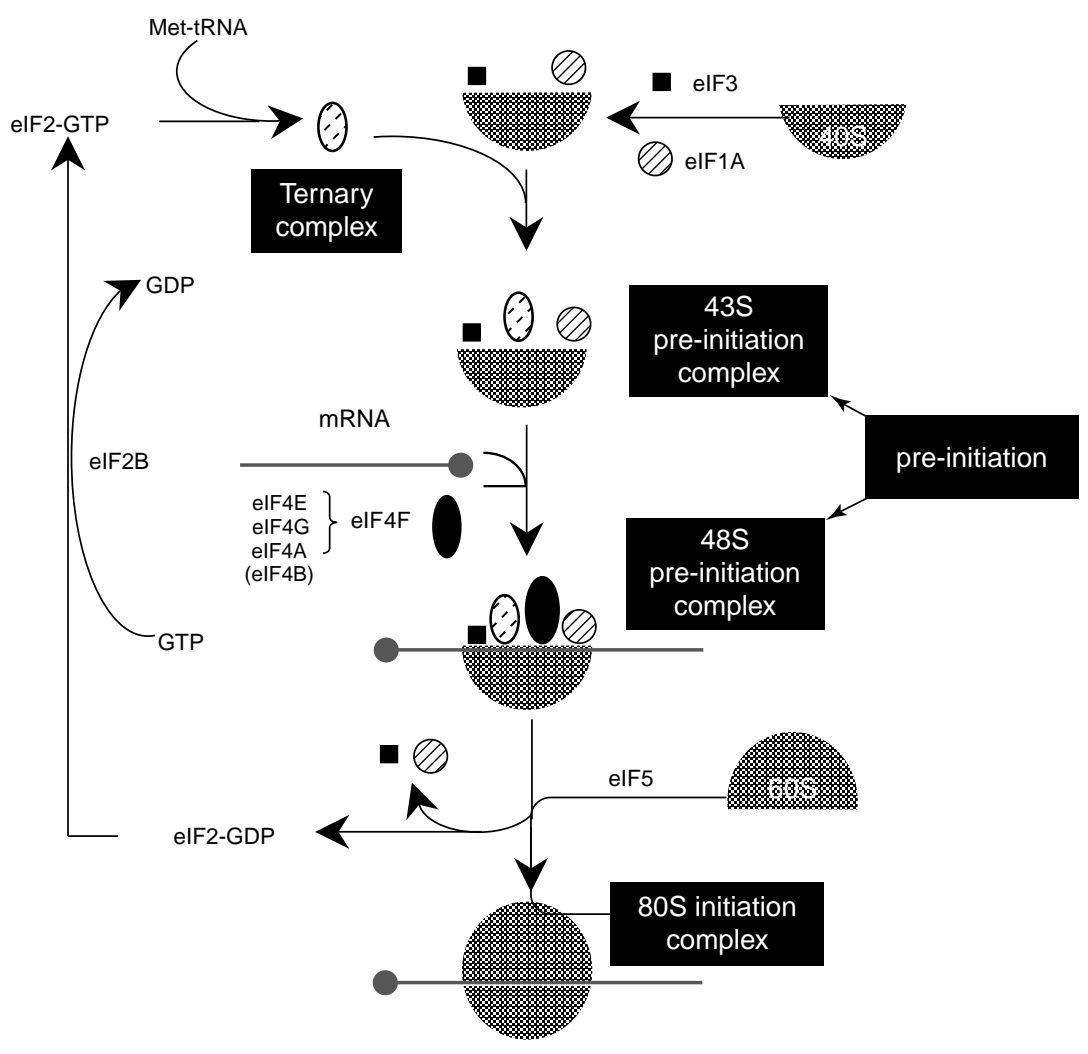

Fig. 1. Representation of the initiation phase of mRNA translation. The first step of protein translation is the formation of the $43 S$ pre-initiation complex containing methionine (Met)-tRNA, eukaryotic initiation factor (eIF) 2, GTP and the 40S ribosomal subunit. The preliminary phase is the activation of elF2. The second step in translation initiation is the binding of mRNA to the $43 \mathrm{~S}$ pre-initiation complex. Proteins collectively referred to as elF4 mediate this step. elF4E binds to the cap structure of the mRNA and forms complexes with the molecular scaffold elF4G, which, in turn, binds the helicase elF4A and the $43 \mathrm{~S}$ ribosomal pre-initiation complex (formation of the $48 \mathrm{~S}$ pre-initiation complex). The third step is the binding of the $60 \mathrm{~S}$ ribosomal subunit to the $48 \mathrm{~S}$ pre-initiation complex to form the active $80 \mathrm{~S}$ initiation complex. 
factors; (2) eukaryotic initiation factor 4E binding protein (4E-BP1); (3) $70 \mathrm{kDa}$ ribosomal protein S6 kinase (p70S6K, also called S6K1). In the present review we provide only brief information concerning these proteins and their participation in the control of the initiation phase of protein synthesis. eIF2 is a protein involved in the first step of the initiation of mRNA translation (Pain, 1996; Kimball, 1999): eIF2 is bound to the $40 \mathrm{~S}$ ribosomal subunit as a ternary complex with GTP and the initiator form of methionyltRNA (Met-tRNAi). Following GTP hydrolysis, the eIF2GDP complex is released from the ribosome. The activity of eIF2 is inhibited when the $\alpha$-subunit of this initiation factor is phosphorylated, leading to the inhibition of protein synthesis. Before binding Met-tRNAi and the formation of a new ternary complex, GDP must be exchanged for GTP, a reaction mediated by eIF2B, which is crucial for translation and its control. Two different mechanisms regulate eIF2B activity: phosphorylation of the $\alpha$-subunit of eIF2 and phosphorylation of the $\varepsilon$-subunit of eIF2B.

The 4E-BP1 and eIF4G proteins share the same binding site for eIF4E, meaning that the binding of 4E-BP1 and eIF4G on eIF4E are mutually exclusive (Proud, 2002). Thus 4E-BP1 acts as a competitive inhibitor of eIF4F complex formation. Dephosphorylated 4E-BP1 binds to the initiation factor eIF4E, and prevents its association with eIF4G. The phosphorylation of 4E-BP1 supports its dissociation from eIF4E, which can then be integrated into the eIF4F complex and consequently allow the formation of the $48 \mathrm{~S}$ preinitiation complex. According to its availability, eIF4E is a limiting element of the initiation of mRNA translation.

As shown by recent studies, p70S6K is a major effector of cell growth. For example, mice deficient for this kinase are smaller than controls and have reduced muscle mass (Pende et al. 2004; Ohanna et al. 2005). p70S6K is a serine/ threonine kinase of the S6 kinase family. S6 kinases were initially characterised for their ability to phosphorylate ribosomal protein S6 (i.e. a component of the 40S ribosomal subunit). The function of S6 phosphorylation is thought to be in inducing the selective translation of $5^{\prime}$ TOP mRNA, a subset of mRNA that possess a terminal $5^{\prime}$-oligopyrimidine tract (Dufner \& Thomas, 1999; Meyuhas, 2000). The 5'TOP mRNA encodes components of the translational machinery such as eukaryotic elongation factors and ribosomal proteins, and, by up regulating their translation, S6 phosphorylation probably leads to an increase in the capacity of the cell to synthesise protein. p70S6K, and similarly 4E-BP1, are phosphorylated in response to insulin via a signal transduction pathway involving phosphatidylinositol-3'kinase (PI3K) and the mammalian target of rapamycin (mTOR). Amino acid signalling also originates from mTOR, and activates p70S6K and 4E-BP1.

\section{Mediators of the early steps of insulin signal transduction}

In mammals, insulin binding to its cognate tyrosine kinase receptor induces tyrosine phosphorylation of various substrates and activation of two main signalling pathways, i.e. the PI3K and the mitogen-activated protein kinase (MAPK) pathways (Fig. 2).

\section{Insulin receptor}

The IR belongs to the large family of cell-surface receptors possessing intrinsic tyrosine kinase activity (Czech, 1985). The structure of the chicken IR is very similar to that known in mammals. The chicken IR is composed of two extracellular $\alpha$-subunits (about $135 \mathrm{kDa}$ ) and two transmembrane $\beta$-subunits (about $95 \mathrm{kDa}$ ) linked together by disulfide bonds (Endo \& Elsas, 1984; Adamo et al. 1987). However, as in mammals, the size of the $\alpha$-subunit of the chicken brain IR is smaller (about $10 \mathrm{kDa}$ ) than that of liver receptors (Simon \& Leroith, 1986). The binding of the ligand to the $\alpha$-subunit leads to conformational changes, resulting in stimulation of the $\beta$-subunit intrinsic tyrosine kinase activity with ensuing multi-site autophosphorylation of the $\beta$-subunit. The tyrosine kinase activity of the chicken IR is similar to that of the human IR (Kato et al. 2000).

Typical IR have also been characterised in a stable and permanent hepatoma cell line ( $\mathrm{LMH}$; Kawaguchi et al. 1987): LMH cells have an $\alpha$-subunit of $135 \mathrm{kDa}$ and a $\beta$-subunit of $95 \mathrm{kDa}$ (Taouis et al. 1993). After autophosphorylation, wheat-germ agglutinin-purified LMH IR also revealed a tyrosine phosphorylated protein of $72 \mathrm{kDa}$, corresponding to either a truncated $\beta$-subunit or a $\beta$-subunit degradation product. It is not present in either chicken liver or cultured hepatocytes, and has never been described in mammal tissues. IR are less numerous in the liver and thymus in the chicken than in the rat (Simon et al. 1977; Cramb et al. 1982). This may explain some of the unusual features of carbohydrate metabolism in the chicken (basal hyperglycaemia and relative insulin resistance).

\section{Insulin receptor substrates: insulin receptor substrate-1 and Src homology and collagen protein}

Upon activation and multi-site autophosphorylation, the mammalian IR phosphorylates cellular substrates on tyrosine. The family of IR substrates (IRS) currently contains several members including IRS-1 (Sun et al. 1991), IRS-2 (Patti et al. 1995), IRS-3 (Lavan et al. 1997), IRS-4 (Fantin et al. 1998) and Src homology and collagen protein (Shc) (Pelicci et al. 1992). IRS-1 is one of the major substrates of the IR. It has an amino-terminal phosphotyrosine binding domain which is crucial for the interaction with phosphorylated IR. It also contains multiple tyrosine phosphorylation motifs that serve as docking sites for Src-homology 2 (SH2)-domain-containing proteins such as the adapters for PI3K (Backer et al. 1992) and Grb2 (Skolnik et al. 1993), which mediate the metabolic and growth-promoting functions of insulin. IRS-1 also contains over thirty potential serine/threonine phosphorylation sites, which may be involved in the desensitisation of insulin action and represent a potential mechanism for insulin resistance in some models of obesity (Johnston et al. 2003; Le Marchand-Brustel et al. 2003; Zick, 2004). Recent studies have shown that IRS-1 phosphorylation on specific residues, including Ser307, Ser612 and Ser632/Ser635, plays a negative role in insulin signalling; phosphorylation of these sites is mediated by MAPKinase and/or the mTOR/ p70S6K pathway (Ozes et al. 2001; Greene et al. 2003; Jiang et al. 2004; Khamzina et al. 2005). 


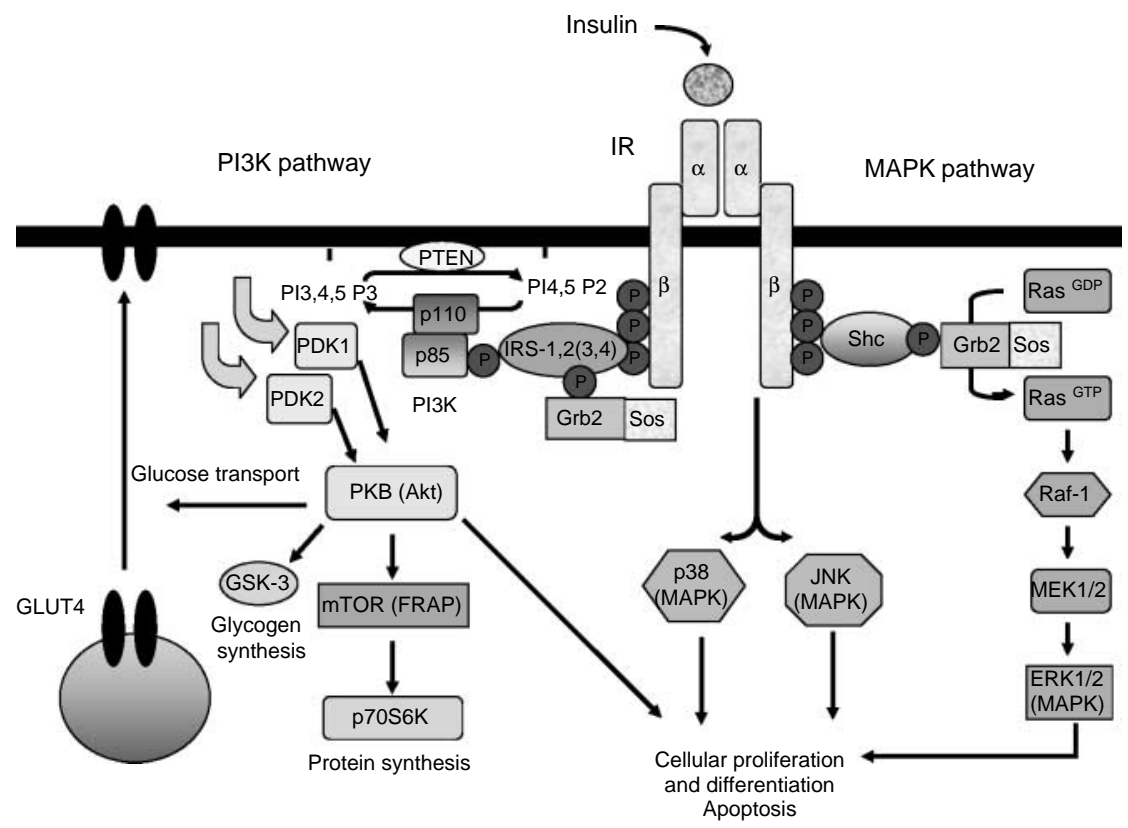

Fig. 2. General outline of pathways stimulated by insulin in mammalian target cells. PI3K, phosphatidylinositol-3'kinase; IR, insulin receptor; MAPK, mitogen-activated protein kinase; PTEN, phosphatase and tensin homologue; PI 4,5 P2, phosphatidylinositol-4,5-biphosphate; PI 3,4,5 P3, phosphatidylinositol-3,4,5-triphosphate; PDK, phosphoinositide-dependent kinase; IRS, IR substrate; Shc, Src homology and collagen protein; Grb2, growth factor receptor-bound protein 2; Sos, Son-of-sevenless; PKB (Akt), protein kinase B; Raf, MAPK kinase kinase; GSK, glycogen synthase kinase; mTOR (FRAP), mammalian target of rapamycin; JNK, c-Jun amino-terminal kinase; MEK, Map/Erk kinase (MAPK kinase); p70S6K, $70 \mathrm{kDa}$ ribosomal protein S6 kinase.

The coding region of the IRS-1 gene has been cloned and sequenced in the chicken (Taouis et al. 1996). Chicken IRS1 presents high sequence identity with its human, rat and mouse homologues (Taouis et al. 1996). The most conserved regions are the pleckstrin homology (PH) domain, the IRS-1 homology 2 (IH2), Shc and IRS-1 NPXY-binding (SAIN) domains, and the twelve tyrosine residues that are located in YXXM and YMXM motifs. Chicken IRS-1 is present in the liver and muscle and interacts with chicken IR. Interestingly, tyrosine phosphorylation of chicken IRS-1 is dependent on nutritional state in the liver but not in muscle (Dupont et al. 1998b), suggesting tissue-specific regulation and relative insulin resistance in muscle in the chicken. In the chicken hepatoma cell line (LMH cells), chicken IRS-1 repression has been shown to induce a substantial increase in Shc expression (Taouis et al. 1998). Shc is also phosphorylated on tyrosine residues in response to insulin and therefore serves as another IRS. In the absence of IRS-1, Shc might represent an alternative pathway to transduce insulin signalling.

Mammalian Shc proteins include three isoforms that are encoded by the same gene $(46,52$ and $66 \mathrm{kDa}$; Pelicci et al. 1992). Shc isoforms and IRS proteins have an N-terminal phosphotyrosine binding domain in common which serve for the interaction with phosphorylated IR (Gustafson et al. 1995). Furthermore, Shc proteins have a central glycine/ praline-rich region, which interacts with proteins containing an Src-homology 3 domain and a carboxyl terminal $\mathrm{SH} 2$ domain. Phosphorylation of Shc by the IR has been reported in different transformed-cell models. IR appears to phosphorylate the $52 \mathrm{kDa}$ isoform preferentially. In the chicken, the three Shc isoforms are present in the liver and muscle (Dupont et al. 1998a). Interestingly, the tyrosine phosphorylation of Shc $(52 \mathrm{kDa})$ is dependent upon nutritional state and increases after insulin injection in both chicken liver and muscle (Dupont et al. 1998a, 2004). Shc, mainly the $52 \mathrm{kDa}$ isoform, interacts with IR whereas the $46 \mathrm{kDa}$ isoform associates with IRS-1. The consequences of these preferential associations of Shc isoforms in terms of biological effects remain to be specified. The $52 \mathrm{kDa}$ Shc isoform also interacts with the regulatory subunit of PI3K. Shc $(52 \mathrm{kDa})$ is thus a key substrate for the IR in the chicken because it is able first to associate with PI3K and, in contrast to IRS-1, it is also phosphorylated in muscle in response to insulin injection or re-feeding. The possible existence of different subtypes of IR complexes signalling through IRS-1 or Shc has been investigated in the liver, and the presence of a large complex involving IR, IRS1 , Shc (mainly the $52 \mathrm{kDa}$ isoform) and the regulatory subunits of PI3K has been demonstrated; another complex, including IRS-1 and the $46 \mathrm{kDa}$ Shc isoform, is also present (Dupont et al. 1998a; Fig. 3). These interactions have never been described in mammal tissue.

\section{Phosphatidylinositol-3'kinase and its specific inhibitor, phosphatase and tensin homologue}

Once tyrosine phosphorylated, IRS-1 is able to associate with different proteins with an SH2 domain, including PI3K. $\mathrm{PI} 3 \mathrm{~K}$ is a dimer composed of a $110 \mathrm{kDa}$ catalytic subunit that is associated non-covalently with a 55 or $85 \mathrm{kDa}$ regulatory subunit (Foster et al. 2003). PI3K is activated 


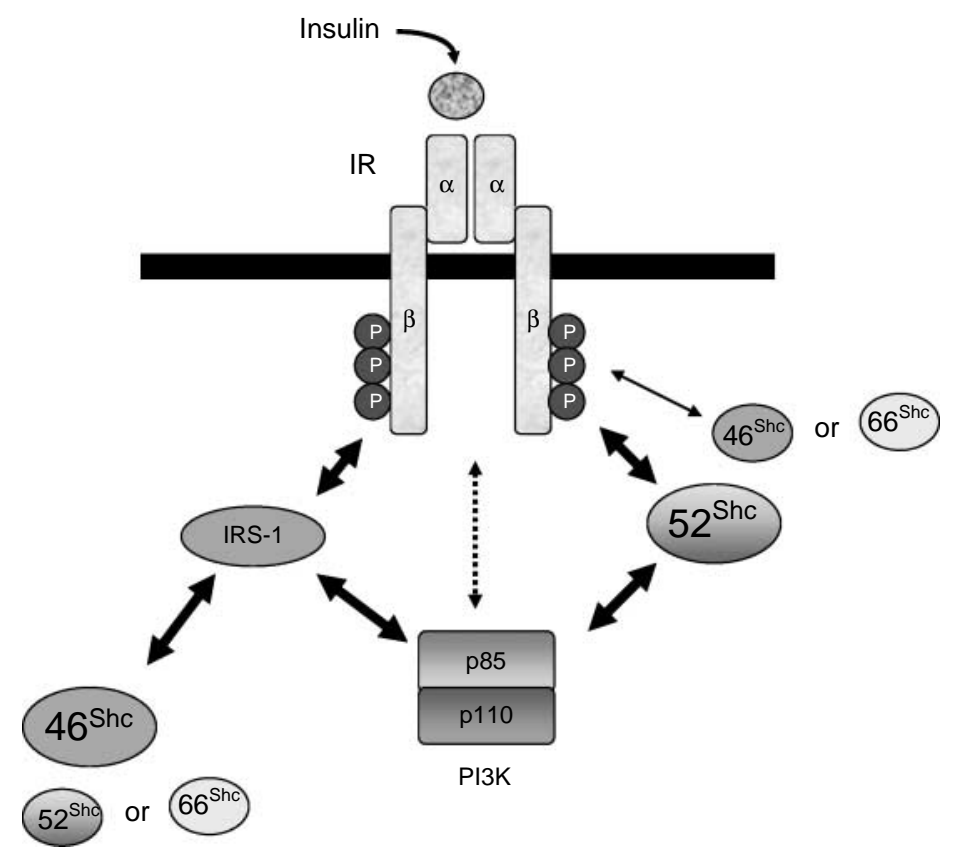

Fig. 3. Interactions between insulin receptor (IR), IR substrate (IRS)-1, Src homology and collagen protein (Shc) and the regulatory subunits of phosphatidylinositol-3'kinase (PI3K) in the chicken liver (adapted from Dupont et al. 1998a).

when the phosphorylated YMXM motifs in IRS proteins occupy SH2 domains in the regulatory subunit (Backer et al. 1992). These SH2-phosphotyrosine interactions bring $\mathrm{PI} 3 \mathrm{~K}$ in close proximity to its substrate on the plasma membrane and relieve the inhibitory action of p85 (a regulatory subunit of $\mathrm{PI} 3 \mathrm{~K}$ ) on the $\mathrm{p} 110$ catalytic subunit, which is then free to convert phosphatidylinositol-4,5biphosphate into phosphatidylinositol-3,4,5-triphosphate (PIP3). The main consequence of PI3K activation is the generation of PIP3 in the membrane, which functions as a second messenger to activate downstream pathways that involve different serine/threonine kinases (Fig. 2). There is convincing evidence that PI3K plays a central role in insulin signalling in mammals (for a review, see Shepherd et al. 1998). Moreover, it has been shown that insulin stimulation of PI3K in muscle and adipose tissues was greatly decreased in some insulin-resistance and diabetes models.

In the chicken, PI3K has been characterised in vivo in two target tissues (liver and muscle; Dupont et al. 1998a) and in vitro in LMH cells (Taouis et al. 1998). The degree of PI3K activation in the liver depends on nutritional state (fasting $v$. re-feeding) in several experimental models (Dupont et al. $1998 a, 1999 a, b)$. This is in agreement with the modifications of the insulin-signalling cascade (i.e. tyrosine phosphorylation of IR $\beta$-subunit, IRS-1 and Shc) according to nutritional state. Conversely, the PI3K activity associated with tyrosine phosphorylated proteins in muscle is largely unresponsive irrespective of experimental models, i.e. usual or experimental conditions known to alter insulin sensitivity such as chronic corticosterone treatment or genetically selected fat and lean lines of chickens; only the phosphorylation of the $52 \mathrm{kDa}$ Shc isoform was reduced by fasting and increased by re-feeding. This phenomenon is apparently specific to the species, as suggested by comparison of the responses to exogenous insulin in chickens and rats (Dupont et al. 2004). Moreover, PI3K activity in muscle is about 30 -fold greater in the chicken than in the rat (Dupont et al. 2004). This hyperactivity of PI3K observed in chicken muscle could overstimulate a feedback inhibition pathway desensitising chicken muscle. Indeed, it has been shown that some serine/threonine kinases, including mammalian PI3K, can act as a serine/ threonine kinase, exerting feedback inhibition on IR signalling by phosphorylating at least IRS-1 on serine residues (Greene et al. 2003). However, this hypothesis remains to be confirmed in chicken muscle.

Phosphatase and tensin homologue (PTEN) is a dualspecificity phosphatase that has activity against both lipid and protein substrates (Maehama et al. 2001). Indeed, it dephosphorylates PIP3 generated by PI3K and also some peptide substrates both in vitro and in vivo. Studies in Drosophila have shown that the growth-regulatory functions of PTEN are primarily mediated via its lipid phosphatase activity (Goberdhan \& Wilson, 2003). This activity antagonises the effects of activated PI3K in the nutritionally controlled IR pathways, thereby reducing protein synthesis and restraining cell and organism growth, while also regulating other biological processes, such as fertility and ageing. PTEN can also reduce phosphorylation of IRS-1, MAPK extracellular signalregulated protein kinase (ERK) $1 / 2$ (Weng et al. 2001) and focal adhesion kinase (Yamada \& Araki, 2001). There is evidence suggesting that PTEN is a regulator of insulin sensitivity in the insulin target tissue. Diabetic $\mathrm{db} / \mathrm{db}$ mice were shown to be protected from developing diabetes when PTEN was specifically inhibited by using an antisense oligonucleotide strategy (Butler et al. 2002). Moreover, polymorphisms of PTEN have been described 
in association with type 2 diabetes in a Japanese cohort (Ishihara et al. 2003). It has recently been demonstrated that muscle-specific deletion of PTEN protected mice against the development of fat- and age-dependent insulin resistance and diabetes without the development of cancer (Wijesekara et al. 2005). However, the physiological function of PTEN in skeletal muscle is poorly documented, and its role in the occurrence of insulin resistance remains unclear. We have identified PTEN in chicken tissues and are investigating its role, particularly in muscle (Vaudin et al. 2006). This PTEN phosphatase could contribute to explaining the relative insulin insensitivity of the early steps of insulin signalling in chicken muscle.

Overall, the results concerning the early steps of chicken IR signalling have shown that the level of tyrosine phosphorylation of the IR $\beta$-subunit, IRS- 1 and the PI3K activity in muscle were not modified in any of the experimental conditions. Therefore, although the insulin cascade is normally responsive in the chicken liver, it appears 'refractory' in muscle. The fact that PI3K activity and the amount of p85 expressed in chicken muscle are high compared with mammals may contribute to this state, making chicken muscle an interesting model of insulin resistance. There are several possible explanations for these particular features. For example, a high level of phosphorylation on serine residues of the IR and IRS- 1 is known to limit the ability of insulin to stimulate the phosphorylation of these molecules on tyrosine residues and to activate subsequent steps. Interestingly, we recently observed a high level of IRS-1 phosphorylation on Ser636/Ser639 in chicken muscles (S Duchene, S Metayer, E Audouin, J Dupont, K Bigot and S Tesseraud, unpublished results). PTEN could also play a significant role as an inhibitor of the PI3K pathway.

\section{Serine/threonine kinases involved in insulin and amino acid signalling}

\section{Phosphoinositide-dependent kinase 1}

Phosphoinositide-dependent kinase (PDK) 1 is a protein kinase that phosphorylates and activates several other protein kinases from the AGC group (which includes protein kinase $A$, protein kinase $\mathrm{G}$ and protein kinase $\mathrm{C}$ (PKC)), to which PDK1 also belongs (Mora et al. 2004). Recombinant PDK1 phosphorylates another key kinase in insulin action, i.e. protein kinase B (PKB or Akt), directly on Thr308, in a reaction that is almost completely dependent on PIP3. The second messenger PIP3 binds to the PH domains of PDK1 and $\mathrm{PKB} / \mathrm{Akt}$ upon insulin stimulation of cells. This colocalises the kinases on the plasma membrane and makes it possible for PDK1 phosphorylation of PKB/Akt to proceed in a phosphoinositide manner (Belham et al. 1999). The discovery of PDK1 as one of the kinases responsible for the PIP3-dependent phosphorylation of the PKB activation loop immediately raises the possibility that PDK1 might also act on other protein kinases previously shown to be activated downstream from PI3K, especially p70S6K (Alessi et al. 1998) and the atypical PKC $\lambda / \tau$ and $\zeta$. PDK1 has not yet been identified in the chicken.

\section{Protein kinase $B$}

Akt encodes a serine/threonine kinase that has an aminoterminal PH domain, a central catalytic domain and a short carboxy-terminal regulatory domain (Hanada et al. 2004). There are three members of the Akt family in mammals (Akt1, Akt2 and Akt3) which are widely expressed, although there are some isoform-specific features. Akt is activated by a dual regulatory mechanism that requires both translocation to the plasma membrane and phosphorylation at Thr308 and Ser473. The generation of PIP3 on the membrane following PI3K activation recruits Akt by direct interaction with its $\mathrm{PH}$ domain. PDK1 phosphorylates Akt on Thr308. However, maximal activation requires additional phosphorylation at Ser473 by a hydrophobic motif kinase called PDK2 (Fig. 2). The molecular identity of this Ser473 kinase has been debated for many years, and at least ten kinases have been proposed to be PDK2 (Dong \& Liu, 2005). Recently, Sarbassov et al. (2005) have demonstrated a mechanism for regulating the phosphorylation of Akt on Ser473 by the rapamycin-insensitive companion of mTOR (rictor)-mTOR complex (for more details on rictor and mTOR, see p. 110). Activated Akt phosphorylates many substrates to control various biological signalling cascades, including glucose transport, glycogen synthesis, cell proliferation, cell survival and, for what concerns us in the present review, protein synthesis in various cells and tissues (Whiteman et al. 2002; Fig. 2).

In the chicken, Akt has been identified in spinal cord motor neurons in vitro (Egea et al. 2001), and in granulosa cells (Johnson et al. 2001) and muscle in vivo (Bigot et al. 2003a; Halevy et al. 2003). The phosphorylation of Akt on Ser473 is increased after hatching in early-feeding chicks (Bigot et al. 2003a). This latter result was not observed in $48 \mathrm{~h}$ delayed-feeding chicks (i.e. very low levels during post-hatching starvation) and Akt phosphorylation was increased only after food supply. Insulin may be involved in Akt activation in chicken muscle, despite the fact that chickens exhibit particular features in the insulin-signalling cascade (IR/IRS-1/PI3K pathway).

\section{Role of protein kinase mammalian target of rapamycin}

In addition to its role in proliferation, there is growing evidence that Akt also affects cell growth. Proliferation refers to cell division, which leads to an increase in cell numbers, whereas growth refers to the synthesis of macromolecules, which results in increased cell mass or size. One protein that is emerging as a central regulator of cell growth is mTOR (also known as FRAP1), a serine/threonine kinase that serves as a molecular sensor that regulates protein synthesis on the basis of the availability of nutrients (Beugnet et al. 2003; Bolster et al. 2004; Hay \& Sonenberg, 2004). mTOR is a direct target of Akt (Nave et al. 1999), and its activity can be suppressed by the PI3K inhibitors wortmannin and LY294002. Insulin and insulin-like growth factor-1 regulate $\mathrm{mTOR}$ through the sequential activation of a series of upstream kinases including PI3K and PKB/Akt. $\mathrm{PKB} /$ Akt phosphorylates Ser2448 of mTOR in vitro, and insulin induces phosphorylation of this residue in cells in 
culture (Reynolds et al. 2002). Phosphorylation of Ser2448 in response to insulin is blocked by either amino acid deprivation or by treatment with the PI3K inhibitor wortmannin (Nave et al. 1999). Despite these findings, the role of Ser2448 in the regulation of mTOR activity remains unclear since its replacement for Ala seems to have no effect on mTOR function (Sekulic et al. 2000). Pharmacological studies with the mTOR inhibitor rapamycin indicate that the Akt pathway regulates muscle cell growth through mTOR (Bodine et al. 2001). Muscle hypertrophy that is induced by either insulin-like growth factor-1 or the expression of a constitutively active form of Akt is reversed by rapamycin treatment (Rommel et al. 2001). Interestingly, a recent study has shown that mTOR regulates the phosphorylation of IRS1 on Ser307 in 3T3-L1 cells (Carlson et al. 2004). Phosphorylation of IRS-1 on Ser307 has been shown to negatively regulate insulin-stimulated tyrosine phosphorylation of IRS-1 and PI3K activity. Similarly, the phosphorylation of IRS-1 on Ser636/Ser639 mediated by mTOR plays a negative role in insulin signalling and could represent a potential mechanism for insulin resistance in some models of obesity (Ozes et al. 2001; Khamzina et al. 2005).

The mechanisms through which mTOR signals and how its activity is regulated were undefined until recently. However, several recent reports have described the identification of proteins that modulate insulin and/or amino acid signalling through $\mathrm{mTOR}$, i.e. the tuberous sclerosis complex (TSC) proteins, TSC1 (also known as hamartin) and TSC2 (also known as tuberin), and the small GTPase Rheb (Ras homologue enriched in brain) protein (Harris \& Lawrence, 2003; Kimball \& Jefferson, 2004a; Li et al. 2004). A particularly attractive hypothesis derived from studies in mammals and Drosophila identifies TSC 2 as a GTPase activator protein for Rheb that is inhibited by amino acids, allowing Rheb to activate mTOR through a mechanism still to be defined. TSC2 is also directly phosphorylated and inhibited by Akt, which is activated by growth-stimulating signals such as insulin (Inoki et al. 2002). It should be noted that AMPK (an energy sensor) may signal through TSC2 to down regulate the activity of mTOR and its downstream effectors (4E-BP1, p70S6K; Hardie, 2004). In addition, several laboratories have identified different mTOR-associated proteins, such as regulatory associated protein of $\mathrm{mTOR}$ (raptor) and mLST8 (also known as G $\beta \mathrm{L}$, i.e. G protein $\beta$-subunit-like protein) (Hara et al. 2002; Loewith et al. 2002; Kim et al. 2002, 2003). There is general agreement that raptor is important for TOR signalling in different organisms (yeast, mammals). Although there are different models for the influence of raptor on mTOR (reported in Harris \& Lawrence, 2003), it seems that amino acids activate the mTOR pathway through a mechanism that involves destabilisation of the interaction between raptor and mTOR. More recently, a novel partner of mTOR has been discovered, referred to as rictor, which exists in a protein complex containing rictor, mTOR and GßL, but not raptor (Sarbassov et al. 2004). Whereas the raptor-mTOR complex phosphorylates the mTOR effector p70S6K, therefore promoting mRNA translation, the rictor-mTOR complex does not but is involved in Akt regulation (Ali \& Sabatini, 2005; Sarbassov et al. 2005).
There remain many questions impairing a full understanding of the mTOR pathway, but the large number of studies currently being performed on the TOR field is not surprising due to its central role in physiological processes. The mTOR pathway is very interesting to study for nutritional application since it is regulated by nutrient availability. Interestingly, there is strong evidence of amino acid control of mRNA translation through a mechanism involving the TOR signalling pathway from mammals to Drosophila (Rohde et al. 2001; Oldham \& Hafen, 2003; Stocker et al. 2003). Similarly, a recent study in our laboratory in a stable and permanent avian myogenic cell line (QM7 cells; Antin \& Ordahl, 1991) showed the involvement of an avian homologue of TOR in the activation of protein synthesis by amino acids (Tesseraud et al. 2003).

\section{Atypical protein kinases $\mathbf{C}$ and mitogen-activated protein kinases}

\section{Atypical proteins: protein kinases $C \lambda \tau$ and $\zeta$}

In mammals, insulin activates certain atypical proteins involved, for example, in cell-cycle progression or glucose transport. Atypical PKC $\lambda / \tau$ and $\zeta$ show modest activation after IR kinase stimulation which appears to be both PI3K dependent and independent. Although these PKC lack PH domains, they probably do interact with PIP3, as it is one of the phospholipids capable of supporting their maximal activity in vitro. A number of reports have indicated that the $\mathrm{PI} 3 \mathrm{~K}$-dependent activation of these PKC is mediated by PDK1. Considerable evidence suggests that atypical PKC isoforms, acting downstream from IRS and PI3K, are required for insulin-stimulated glucose transport in skeletal muscle and adipocytes (Farese, 2002). In addition, PKC $\lambda$ and $\zeta$ are able to regulate p70S6K involved in protein synthesis (Akimoto et al. 1998; Romanelli et al. 1999).

\section{Mitogen-activated protein kinase pathway: involvement of extracellular signal-regulated kinases 1 and 2}

The PI3K/Akt cascade is the main signalling pathway involved in protein synthesis in response to insulin. However, some studies have indicated that MAPK ERK1/2 might also be involved in this process (Table 1). All eukaryotic cells possess multiple MAPK pathways, which together regulate various cellular activities (gene expression, cell proliferation, survival and apoptosis and differentiation). Five distinct groups of MAPK have been characterised to date in mammals: ERK1 and ERK2, c-Jun amino-terminal kinases (JNK) 1, 2 and 3,p38 isoforms $\alpha, \beta$, $\gamma$ and $\delta$, ERK3 and 4, and ERK5 (for reviews, see Chen et al. 2001; Kyriakis \& Avruch, 2001). Among the several forms of ERK, the $44 \mathrm{kDa}$ (ERK1) and $42 \mathrm{kDa}$ (ERK2) forms have been the most widely studied. The ERK1/2 MAPK pathway is activated by IRS-1 or Shc tyrosine phosphorylation. It is composed of a set of three sequentially acting kinases: a MAPKK kinase (Raf), a MAPK kinase (MEK1/2) and a MAPK (ERK1/2). The Raf family of serine/threonine kinase consists of three highly conserved members (A-Raf, B-Raf and Raf-1). Raf-1 is ubiquitously expressed whereas A- and B-Raf have a more tissue-specific expression. Raf-1 
Table 1. Signalling pathways involved in insulin-induced protein synthesis

\begin{tabular}{lll}
\hline Cell type or tissue & \multicolumn{1}{c}{ Signalling pathway } & \multicolumn{1}{c}{ Reference } \\
\hline Cardiac myocytes & MAPK ERK1/2 and PKC & Tokudome et al. (2004) \\
Skeletal muscle & PIKK/mTOR & Bolster et al. (2004) \\
Renal epithelial cells & PI3K/mTOR and MAPK ERK1/2 & Bhandari et al. (2001) \\
Breast cancer cell, (MCF-7) & Akt & Faridi et al. (2003) \\
HEK 293 cells & Akt/mTOR & Herbert et al. (2000) \\
L6 myotubes & Akt & Ueki et al. (1998) \\
Epitrochlearis muscle in vitro & PI3K & Dardevet et al. (1996) \\
\hline
\end{tabular}

MAPK, mitogen-activated protein kinase; ERK, extracellular signal-regulated protein kinase; PKC, protein kinase C; PI3K, phosphatidylinositol-3'kinase; mTOR, mammalian target of rapamycin; Akt, protein kinase B.

is the most studied Raf isoform (Hagemann \& Rapp, 1999). The first step in Raf-1 activation by receptor tyrosine kinases such as the IR involves Ras activation (i.e. Ras loading with GTP). Son-of-sevenless (SOS) protein is a guanine nucleotide exchange factor for Ras and causes the conversion of Ras-GDP into Ras-GTP. Then, Ras-GTP recruits Raf-1 to the membrane, thereby promoting its phosphorylation and activation. Raf-1 regulation is a complex process, involving membrane recruitments, intraand intermolecular interactions, and phosphorylationdephosphorylation events that have been the subject of recent reviews (Wellbrock et al. 2004; Baccarini, 2005). Raf- 1 activation leads to the phosphorylation and activation of a MAPK kinase called MEK1/2, which then stimulates MAPK (ERK1/2) activity through dual phosphorylation on threonine and tyrosine residues (Fig. 2). Activated ERK1/2 phosphorylates substrates in both cytoplasmic and nuclear cellular compartments. Activated ERK1/2 is translocated to the nucleus and is capable of phosphorylating many different transcription factors, including Elk-1. MAPK ERK1/2 is necessary for the development of insulin-like growth factor-1-induced skeletal muscle hypertrophy in the rat in vivo (Haddad \& Adams, 2004). In vitro, the MAPK ERK1/2 signalling pathway is involved in the protein synthesis induced by insulin in rat cardiac myocytes and renal epithelial cells (Table 1; Iijima et al. 2002).

MAPK ERK1/2 has been identified in chicken myoblasts (Leshem et al. 2002) and in both embryonic and adult chicken gizzards (Childs \& Mak, 1993), but its role in protein synthesis has not been investigated. However, this signalling pathway may play a crucial role in chicken growth and participate in the insulin-dependent regulation of p70S6K since Shc, which is located upstream in this signalling pathway, seems to be a key substrate for the IR in chicken muscle.

\section{Regulation of p70 S6 kinase and eukaryotic initiation factor $4 \mathrm{E}$ binding protein activity}

As described earlier, insulin and amino acids are positive regulators of mTOR signalling. The targets of the mTOR pathway include 4E-BP1 and p70S6K.

\section{Modulation of eukaryotic initiation factor $4 E$ binding protein activity}

Rapamycin treatment, which inhibits the kinase activity of mTOR and leads to inactivation of p70S6K, also inhibits the phosphorylation of 4E-BP1. In mammals, insulin phosphorylates and activates 4E-BP1. Amino acids also have a marked effect on 4E-BP1 phosphorylation and regulation in many cell types (Kimball, 2002; Kimball \& Jefferson, 2002, 2004b; Proud, 2002, 2004). For example, after the transfer of Chinese hamster ovary cells to a medium deprived of amino acids, 4E-BP1 undergoes dephosphorylation within 15-30 min. In contrast, control cells placed in a medium containing amino acids present little or no binding between 4E-BP1 and eIF4E, and high levels of active eIF4F complex (Hara et al. 1998). The hyperphosphorylation of 4E-BP1 induced by amino acids has also been confirmed in vivo in young rats and pigs (Long et al. 2000; Balage et al. 2001; O'Connor et al. 2003b, 2004) and is associated with increased assembly of the active eIF4E-eIF4G complex. In the chicken, 4E-BP1 has been studied very little. Only one study on chicken embryo fibroblasts has been published (Aoki et al. 2001). These chicken fibroblasts transformed with PI3K and Akt show constitutive phosphorylation of 4E-BP1 and p70S6K, suggesting that targets controlling translation are essential components of oncogenic transformation by PI3K and Akt.

\section{Regulation of p70 S6 kinase activity}

Activation of p70S6K occurs through a complex series of phosphorylation events on eight or more serine or threonine residues located within the catalytic, linker and pseudosubstrate domains (Pullen \& Thomas, 1997). Phosphorylation of Thr229 in the catalytic domain and Thr389 in the linker domain are most critical for kinase function. However, phosphorylation of Thr389 is closely correlated with p70S6K activity in vivo (Weng et al. 1998; Dufner \& Thomas, 1999). Ser411, Thr421 and Ser424 lie within a SerPro-rich region located in the pseudosubstrate region. Phosphorylation at these sites is thought to activate p70 S6 kinase via relief of pseudosubstrate suppression.

p70S6K phosphorylation and activity are controlled by insulin and amino acids in vitro and in vivo (Kimball, 2002; Kimball \& Jefferson, 2002, $2004 a, b$; O'Connor et al. 2003b; Proud, 2002, 2004; Meijer \& Dubbelhuis, 2004; Prod'homme et al. 2004). Inactivation of p70S6K by dephosphorylation at specific sites is possible either through rapamycin treatment (rapamycin binds and inhibits the kinase activity of mTOR) or amino acid deprivation. Another mechanism for dephosphorylation of p70S6K is the activation of a Ser/Thr protein phosphatase that 
dephosphorylates p70S6K at these regulatory sites. It has recently been shown that in 3T3-L1 adipocytes overexpression of phosphatase SHIP2 inhibited insulin-induced phosphorylation of Akt and p70S6K and protein synthesis (Murakami et al. 2004). Thus, phosphatase SHIP2, which possesses a $5^{\prime}$-phosphatase activity specifically to hydrolyse $\mathrm{PI} 3 \mathrm{~K}$ products, might play an important role in the negative regulation of insulin signalling for protein synthesis.

In avian species, p70S6 kinase has been characterised in the quail muscle (QM7) cell line and in chicken skeletal muscles (Tesseraud et al. 2003; Bigot et al. 2003a,b). This kinase is regulated by amino acids through signaltransduction pathways involving TOR and/or PI3K (Tesseraud et al. 2003). Moreover, the availability of individual amino acids (methionine and leucine) also regulates p70S6K phosphorylation and protein synthesis in QM7 cells. In the chicken, p70S6K activity is significantly increased in both pectoralis and gastrocnemius muscles after re-feeding for $30 \mathrm{~min}$ following $16 \mathrm{~h}$ starvation and also after a single insulin injection (Bigot et al. 2003b). Similarly, p70S6K is correlated with plasma insulin level in the muscle of neonatal chicks, suggesting probable insulindependent p70S6K activation (Bigot et al. 2003a). These results are surprising considering the relative insulin resistance of chicken muscle to exogenous insulin (Dupont et al. 2004) and the lack of re-feeding-related response of chicken muscle PI3K (Dupont et al. 1998a). However, p70S6K has recently been identified as being involved in a feedback loop, which attenuates the ability of insulin to activate PI3K. Indeed, there is evidence that p70S6K negatively regulates insulin signalling by increasing the serine/threonine phosphorylation of IRS-1 (Tremblay \& Marette, 2001; Um et al. 2004; Harrington et al. 2005). p70S6K could thus have a function in the development of obesity and insulin resistance.

\section{Conclusion}

As in mammals, amino acids and insulin in the chicken have a determining role in the regulation of protein synthesis, via mechanisms of action more specifically targeted on the initiation of mRNA translation. The mediators of signal transduction characterised at the present time in the chicken have a high sequence identity with those of mammals. There are, however, particular characteristics concerning insulin regulation in the chicken; this species presents a relative resistance to exogenous insulin of mammal origin, and refeeding or insulin injection does not lead to an activation of the early steps of IR signalling in muscle (IRS1/PI3K pathway). Taken together, these results suggest the intervention of signalling pathways or regulation mechanisms that are different in the chicken from those described in mammals. Why does muscle tissue present relative insulin resistance? Is it an intrinsic characteristic of the species or is it observed only in broiler chickens? Indeed, it is important to keep in mind that the chicken lines used in the studies referred to in the literature are broiler chickens, selected for high $v$. low growth rates and with a potential to develop 'metabolic disorders'. Comparison of genetically selected experimental lines of chickens (high $v$. low growth rates) might provide new evidence to explain the particular features of insulin action and signalling in chickens.

Both amino acids and insulin control mRNA translation, and the signalling pathways involved present similarities or at least common actors. Whether or not there are interactions between insulin and amino acids in the regulation of chicken muscle protein synthesis remains unknown. In vitro studies in an avian QM7 cell line did not resolve these issues; the stimulation of p70S6K activity in response to amino acids occurs independently of insulin action since there is no IR on the surface of these cells (Tesseraud et al. 2003). The study of the respective roles of insulin and amino acids is difficult in vivo because of the concomitant changes in the concentrations of these factors in the majority of experiments. Indeed, any hyperaminoacidaemia involves an increase in insulin secretion. Due to their capacity to control protein turnover (in particular proteolysis), the changes in insulinaemia involve changes in aminoacidaemia. Some authors have approached these problems by using sophisticated experimental models in mammals (transitory hypoinsulinaemia and stimulation of insulinaemia and/or aminoacidaemia by a meal or perfusions; Balage et al. 2001; O'Connor et al. 2003a; Prod'homme et al. 2004, 2005). The fact that chickens present unusual characteristics in insulin action could suggest that these characteristics are also possible at the level of regulation by amino acids, which must also be studied.

Activation of muscle p70S6K but not of the early steps of the IR cascade remains a mystery but demonstrates that, although apparently refractory, chicken muscle is not totally insensitive to insulin. This is also suggested by the major hyperglycaemic effect of injecting anti-insulin serum (Simon et al. 2000). However, the pathways involved in the action of insulin in chicken muscle remain to be elucidated. Hyperphosphorylation on serine residues of the IR $\beta$-subunit and IRS-1 might limit the ability of insulin to stimulate the phosphorylation of these molecules on tyrosine residues and to activate subsequent steps. Additional studies on insulin signalling are needed and may contribute to the understanding of specific insulin regulation in the chicken. These characteristics of the avian model represent progress in the comprehension of regulation mechanisms in other species.

\section{Acknowledgements}

The authors would like to thank M. Balage and S. Mordier (INRA, 63122 St Genes, France) for helpful comments and suggestions.

\section{References}

Adamo M, Simon J, Rosebrough RW, McMurtry JP, Steele NC \& LeRoith D (1987) Characterization of the chicken muscle insulin receptor. General Comparative Endocrinology 68, 456-465.

Akiba Y, Chida Y, Takahashi T, Ohtomo Y, Sato K \& Takahashi K (1999) Persistent hypoglycemia induced by continuous insulin infusion in broiler chickens. British Poultry Science 40, $701-705$. 
Akimoto K, Nakaya M, Yamanaka T, Tanaka J, Matsuda S, Weng QP, Avruch J \& Ohno S (1998) Atypical protein kinase C $\lambda$ binds and regulates p70 S6 kinase. Biochemical Journal 335, 417-424.

Alessi DR, Kozlowski MT, Weng QP, Morrice N \& Avruch J (1998) 3-Phosphoinositide-dependent protein kinase 1 (PDK1) phosphorylates and activates the p70 S6 kinase in vivo and in vitro. Current Biology 8, 69-81.

Ali SM \& Sabatini DM (2005) Structure of S6 kinase 1 determines whether raptor-mTOR or rictor-mTOR phosphorylates its hydrophobic motif site. Journal of Biological Chemistry 280, 19445-19448.

Antin PB \& Ordahl CP (1991) Isolation and characterization of an avian myogenic cell line. Developmental Biology 143, $111-121$.

Aoki M, Blazek E \& Vogt PK (2001) A role of the kinase mTOR in cellular transformation induced by the oncoproteins $\mathrm{P} 3 \mathrm{k}$ and Akt. Proceedings of the National Academy of Sciences USA 98, 136-141.

Baccarini M (2005) Second nature: biological functions of the Raf1 kinase. FEBS Letters 579, 3271-3277.

Backer JM, Myers MG Jr, Shoelson SE, Chin DJ, Sun XJ, Miralpeix M, Hu P, Margolis B, Skolnik EY \& Schlessinger J (1992) Phosphatidylinositol 3'-kinase is activated by association with IRS-1 during insulin stimulation. EMBO Journal 11, 3469-3479.

Balage M, Sinaud S, Prod'homme M, Dardevet D, Vary TC, Kimball SR, Jefferson LS \& Grizard J (2001) Amino acids and insulin are both required to regulate assembly of the eIF4E. eIF4G complex in rat skeletal muscle. American Journal of Physiology 281, E565-E574.

Belham C, Wu S \& Avruch J (1999) Intracellular signalling: PDK1 - a kinase at the hub of things. Current Biology 11, R93-R96.

Beugnet A, Tee AR, Taylor PM \& Proud CG (2003) Regulation of targets of mTOR (mammalian target of rapamycin) signalling in intracellular amino acid availability. Biochemical Journal 372, $555-566$.

Bhandari BK, Feliers D, Duraisamy S, Stewart JL, Gingras AC, Abboud HE, Choudhury GG, Sonenberg N \& Kasinath BS (2001) Insulin regulation of protein translation repressor 4E$\mathrm{BP} 1$, an eIF4E-binding protein in renal epithelial cells. Kidney International 59, 866-875.

Bigot K, Taouis M, Picard M \& Tesseraud S (2003a) Early posthatching starvation delays P70 S6 kinase activation in the muscle of neonatal chicks. British Journal of Nutrition 90, 1023-1029.

Bigot K, Taouis M \& Tesseraud S (2003b) Refeeding and insulin regulate S6K1 activity in chicken skeletal muscles. Journal of Nutrition 133, 369-373.

Bodine SC, Stitt TN, Gonzalez M, Kline WO, Stover GL, Bauerlein R, Zlotchenko E, Scrimgeour A, Lawrence JC, Glass DJ \& Yancopoulos GD (2001) Akt/mTOR pathway is a crucial regulator of skeletal muscle hypertrophy and can prevent muscle atrophy in vivo. Nature Cell Biology 3, 1014-1019.

Bolster DR, Jefferson LS \& Kimball SR (2004) Regulation of protein synthesis associated with skeletal muscle hypertrophy by insulin-, amino acid- and exercise-induced signalling. Proceedings of the Nutrition Society 63, 351-356.

Butler M, McKay RA, Popoff IJ, Gaarde WA, Witchell D, Murray SF, Dean NM, Bhanot S \& Monia BP (2002) Specific inhibition of PTEN expression reverses hyperglycemia in diabetic mice. Diabetes 51, 1028-1034.

Carlson CJ, White MF \& Rondinone CM (2004) Mammalian target of rapamycin regulates IRS-1 serine 307 phosphorylation. Biochemical and Biophysical Research Communications 316, 533-539.
Chen Z, Gibson TB, Robinson F, Silvestro L, Pearson G, Xu B, Wright A, Vanderbilt C \& Cobb MH (2001) MAP kinases. Chemical Reviews 101, 2449-2476.

Childs TJ \& Mak AS (1993) Smooth-muscle mitogen-activated protein (MAP) kinase: purification and characterization, and the phosphorylation of caldesmon. Biochemical Journal 296, $745-751$.

Cramb G, Langslow DR \& Phillips JH (1982) The binding of pancreatic hormones to isolated chicken hepatocytes. General and Comparative Endocrinology 46, 297-309.

Czech MP (1985) The nature and regulation of the insulin receptor: structure and function. Annual Review of Physiology 47, $357-381$.

Dardevet D, Sornet C, Attaix D, Baracos VE \& Grizard J (1994) Insulin-like growth factor-1 and insulin resistance in skeletal muscles of adult and old rats. Endocrinology 134, 1475-1484.

Dardevet D, Sornet C, Vary T \& Grizard J (1996) Phosphatidylinositol 3-kinase and p70 S6 kinase participate in the regulation of protein turnover in skeletal muscle by insulin and insulin-like growth factor I. Endocrinology 137, 4087-4094.

Dong LQ \& Liu F (2005) PDK2: the missing piece in the receptor tyrosine kinase signaling pathway puzzle. American Journal of Physiology 289, E187-E196.

Dufner A \& Thomas G (1999) Ribosomal S6 kinase signalling and the control of translation. Experimental Cell Research 253, $100-109$.

Dupont J, Chen J, Derouet M, Simon J, Leclercq B \& Taouis M (1999a) Metabolic differences between genetically lean and fat chickens are partly attributed to the alteration of insulin signaling in liver. Journal of Nutrition 129, 1937-1944.

Dupont J, Dagou C, Derouet M, Simon J \& Taouis M (2004) Early steps of insulin receptor signaling in chicken and rat: apparent refractoriness in chicken muscle. Domestic Animal Endocrinology 26, 127-142.

Dupont J, Derouet M, Simon J \& Taouis M (1998a) Effect of nutritional state on the formation of a complex involving insulin receptor IRS-1, the $52 \mathrm{kDa}$ Src homology/collagen protein (Shc) isoform and phosphatidylinositol 3'-kinase activity. Biochemical Journal 335, 293-300.

Dupont J, Derouet M, Simon J \& Taouis M (1998b) Nutritional state regulates insulin receptor and IRS-1 phosphorylation and expression in chicken. American Journal of Physiology 274, E309-E316.

Dupont J, Derouet M, Simon J \& Taouis M (1999b) Corticosterone alters insulin signaling in chicken muscle and liver at different steps. Journal of Endocrinology 162, 67-76.

Egea J, Espinet C, Soler RM, Dolcet X, Yuste VJ, Encinas M, Iglesias M, Rocamora N \& Comella JX (2001) Neuronal survival induced by neurotrophins requires calmodulin. Journal of Cell Biology 154, 585-597.

Endo F \& Elsas LJ II (1984) Structural analysis and subunit interaction of insulin receptor from membranes of cultured embryonic chick heart cells. Endocrinology 115, 1828-1837.

Fantin VR, Sparling JD, Slot JW, Keller SR, Lienhard GE \& Lavan BE (1998) Characterization of insulin receptor substrate 4 in human embryonic kidney 293 cells. Journal of Biological Chemistry 273, 10726-10732.

Farese RV (2002) Function and dysfunction of aPKC isoforms for glucose transport in insulin-sensitive and insulin-resistant states. American Journal of Physiology 283, E1-E11.

Faridi J, Fawcett J, Wang L \& Roth RA (2003) Akt promotes increased mammalian cell size by stimulating protein synthesis and inhibiting protein degradation. American Journal of Physiology 285, E964-E972.

Foster FM, Traer CJ, Abraham SM \& Fry MJ (2003) The phosphoinositide (PI) 3-kinase family. Journal of Cell Science 116, 3037-3040. 
Goberdhan DC \& Wilson C (2003) PTEN: tumour suppressor, multifunctional growth regulator and more. Human Molecular Genetics 12, R239-R248.

Greene MW, Sakaue H, Wang L, Alessi DR \& Roth RA (2003) Modulation of insulin-stimulated degradation of human insulin receptor substrate-1 by serine 312 phosphorylation. Journal of Biological Chemistry 278, 8199-8211.

Grizard J, Picard B, Dardevet D, Balage M \& Rochon C (1999) Regulation of muscle growth and development. In Protein Metabolism and Nutrition, EAAP Publication no. 96, pp. 177-201 [GE Lobley, A White and JC MacRae, editors]. Wageningen, The Netherlands: EAAP Publications.

Gustafson TA, He W, Craparo A, Schaub CD \& O'Neill TJ (1995) Phosphotyrosine-dependent interaction of SHC and insulin receptor substrate 1 with the NPEY motif of the insulin receptor via a novel non-SH2 domain. Molecular Cellular Biology $\mathbf{1 5}$ $2500-2508$

Haddad F \& Adams GR (2004) Inhibition of MAP/ERK kinase prevents IGF-I-induced hypertrophy in rat muscles. Journal of Applied Physiology 96, 203-210.

Hagemann C \& Rapp UR (1999) Isotype-specific functions of Raf kinases. Experimental Cell Research 253, 34-46.

Halevy O, Nadel Y, Barak M, Rozenboim I \& Sklan D (2003) Early posthatch feeding stimulates satellite cell proliferation and skeletal muscle growth in turkey poults. Journal of Nutrition 133, 1376-1382.

Hanada M, Feng J \& Hemmings BA (2004) Structure, regulation and function of $\mathrm{PKB} / \mathrm{AKT}$ - a major therapeutic target. Biochimica Biophysica Acta 1697, 3-16.

Hara K, Long X, Yoshino K, Oshiro N, Hidayat S, Tokunaga C, Avruch J \& Yonezawa K (2002) Raptor, a binding partner of target of rapamycin (TOR), mediates TOR action. Cell 110, $177-189$.

Hara K, Yonezawa K, Weng QP, Kozlowski MT, Belham C \& Avruch J (1998) Amino acid sufficiency and mTOR regulate p70 S6 kinase and eIF-4E BP1 through a common effector mechanism. Journal of Biological Chemistry 273, $14484-14494$.

Hardie DG (2004) The AMP-activated protein kinase pathway new players upstream and downstream. Journal of Cell Science 117, 5479-5487.

Harrington LS, Findlay GM \& Lamb RF (2005) Restraining PI3K: mTOR signalling goes back to the membrane. Trends in Biochemical Sciences 30, 35-42.

Harris TE \& Lawrence JC Jr (2003) TOR signaling. Science STKE 212, re15.

Hay N \& Sonenberg N (2004) Upstream and downstream of mTOR. Genes and Development 18, 1926-1945.

Herbert TP, Kilhams GR, Batty IH \& Proud CG (2000) Distinct signalling pathways mediate insulin and phorbol esterstimulated eukaryotic initiation factor $4 \mathrm{~F}$ assembly and protein synthesis in HEK 293 cells. Journal of Biological Chemistry 275, 11249-11256.

Iijima Y, Laser M, Shiraishi H, Willey CD, Sundaravadivel B, Xu L, Mc Dermott PJ \& Kuppuswamy D (2002) c-RAF/MEK/ERK pathway controls protein kinase C-mediated $\mathrm{p} 70^{\mathrm{S} 6 \mathrm{~K}}$ activation in adult cardiac muscle cells. Journal of Biological Chemistry 277, $23065-23075$

Inoki K, Li Y, Zhu TQ, Wu J \& Guan KL (2002) TSC2 is phosphorylated and inhibited by Akt and suppresses mTOR signalling. Nature Cell Biology 4, 648-657.

Ishihara H, Sasaoka T, Kagawa S, Murakami S, Fukui K, Kawagishi Y, Yamazaki K, Sato A, Iwata M, Urakaze M, Ishiki M, Wada T, Yaguchi S, Tsuneki H, Kimura I \& Kobayashi M (2003) Association of the polymorphisms in the $5^{\prime}$-untranslated region of PTEN gene with type 2 diabetes in a Japanese population. FEBS Letters 554, 450-454.
Jiang G, Dallas-Yang Q, Biswas S, Li Z \& Zhang BB (2004) Rosiglitazone, an agonist of peroxisome-proliferator-activated receptor gamma (PPAR gamma), decreased inhibitory serine phosphorylation of IRS-1 in vitro and in vivo. Biochemical Journal 377, 339-346.

Johnson AL, Bridgham JT \& Swenson JA (2001) Activation of the Akt/protein kinase B signaling pathway is associated with granulosa cell survival. Biology of Reproduction 64, $1566-1574$.

Johnston AM, Pirola L \& Van Obberghen E (2003) Molecular mechanisms of insulin receptor substrate protein-mediated modulation of insulin signalling. FEBS Letters 546, 32-36.

Kato H, Okubo Y, Matsumura Y, Roberts CT Jr, Sugahara K \& LeRoith D (2000) The tyrosine kinase activity of the chicken insulin receptor is similar to that of the human insulin receptor. Bioscience Biotechnology and Biochemistry 64, 903-906.

Kawaguchi T, Nomura K, Hirayama Y \& Kitagawa T (1987) Establishment and characterization of a chicken hepatocellular carcinoma cell line, LMH. Cancer Research 47, 4460-4464.

Khamzina L, Veilleux A, Bergeron S \& Marette A (2005) Increased activation of the mammalian target of rapamycin pathway in liver and skeletal muscle of obese rats: possible involvement in obesity-linked insulin resistance. Endocrinology 146, 1473-1481.

Kim DH, Sarbassov DD, Ali SM, King JE, Latek RR, ErdjumentBromage H, Tempst P \& Sabatini DM (2002) mTOR interacts with raptor to form a nutrient-sensitive complex that signals to the cell growth machinery. Cell 110, 163-175.

Kim DH, Sarbassov DD, Ali SM, Latek RR, Guntur KV, Erdjument-Bromage H, Tempst P \& Sabatini DM (2003) GßL, a positive regulator of the rapamycin-sensitive pathway required for the nutrient-sensitive interaction between raptor and mTOR. Molecular Cell 11, 895-904.

Kimball SR (1999) Eukaryotic initiation factor eIF2. International Journal of Biochemistry and Cell Biology 31, 25-29.

Kimball SR (2002) Regulation of global and specific mRNA translation by amino acids. Journal of Nutrition 132, 883-886.

Kimball SR, Farrell PA \& Jefferson LS (2002) Invited review: Role of insulin in translational control of protein synthesis in skeletal muscle by amino acids or exercise. Journal of Applied Physiology 93, 1168-1180.

Kimball SR \& Jefferson LS (2002) Control of protein synthesis by amino acid availability. Current Opinion in Clinical Nutrition and Metabolic Care 5, 63-67.

Kimball SR \& Jefferson LS (2004a) Molecular mechanisms though which amino acids mediate signaling though the mammalian target of rapamycin. Current Opinion in Clinical Nutrition and Metabolic Care 7, 39-44.

Kimball SR \& Jefferson LS (2004b) Regulation of global and specific mRNA translation by oral administration of branchedchain amino acids. Biochemical and Biophysical Research Communications 313, 423-427.

Kimball SR \& Jefferson LS (2005) Role of amino acids in the translational control of protein synthesis in mammals. Seminars in Cell and Developmental Biology 16, 21-27.

Kimball SR, Vary TC \& Jefferson LS (1994) Regulation of protein synthesis by insulin. Annual Review of Physiology 56, 321-348.

Kyriakis JM \& Avruch J (2001) Mammalian mitogen-activated protein kinase signal transduction pathways activated by stress and inflammation. Physiological Reviews 81, 807-869.

Lavan BE, Fantin VR, Chang ET, Lane WS, Keller SR \& Lienhard GE (1997) A novel 160-kDa phosphotyrosine protein in insulin-treated embryonic kidney cells is a new member of the insulin receptor substrate family. Journal of Biological Chemistry 272, 21403-21407.

Le Marchand-Brustel Y, Gual P, Gremeaux T, Gonzalez T, Barres R \& Tanti JF (2003) Fatty acid-induced insulin resistance: role of 
insulin receptor substrate 1 serine phosphorylation in the retroregulation of insulin signalling. Biochemical Society Transactions 31, 152-156.

Leshem Y, Gitelman I, Ponzetto C \& Halevy O (2002) Preferential binding of Grb2 or phosphatidylinositol 3-kinase to the met receptor has opposite effects on HGF-induced myoblast proliferation. Experimental Cell Research 274, 288-298.

Li Y, Corradetti MN, Inoki K \& Guan KL (2004) TSC2: filling the GAP in the mTOR signaling pathway. Trends in Biochemical Sciences 29, 32-38.

Loewith R, Jacinto E, Wullschleger S, Lorberg A, Crespo JL, Bonenfant D, Oppliger W, Jenoe P \& Hall MN (2002) Two TOR complexes, only one of which is rapamycin sensitive, have distinct roles in cell growth control. Molecular Cell 10, 457-468.

Long W, Saffer L, Wei L \& Barrett EJ (2000) Amino acids regulate skeletal muscle PHAS-1 and p70 S6 kinase phosphorylation independently to insulin. American Journal of Physiology 279, E301-E306.

Maehama T, Taylor GS \& Dixon JE (2001) PTEN and myotubularin: novel phosphoinositide phosphates. Annual Review of Biochemistry 70, 247-279.

Meijer AJ \& Dubbelhuis P (2004) Amino acid signalling and the integration of metabolism. Biochemical and Biophysical Research Communications 313, 397-403.

Meyuhas O (2000) Synthesis of the translational apparatus is regulated at the translational level. European Journal of Biochemistry 267, 6321-6330.

Mora A, Komander D, van Aalten DM \& Alessi DR (2004) DR PDK1, the master regulator of AGC kinase signal transduction. Seminars in Cell and Development Biology 15, 161-170.

Murakami S, Sasaoka T, Wada T, Fukui K, Nagira K, Ishihara H, Usui I \& Kobayashi M (2004) Impact of Src homology 2containing inositol $5^{\prime}$-phosphatase 2 on the regulation of insulin signaling leading to protein synthesis in 3T3-L1 adipocytes cultured with excess amino acids. Endocrinology 145, 3215-3223.

Muramatsu T (1990) Nutrition and whole-body protein turnover in the chicken in relation to mammalian species. Nutrition Research Reviews 3, 211-228.

Nave BT, Ouwens M, Withers DJ, Alessi DR \& Shepherd PR (1999) Mammalian target of rapamycin is a direct target for protein kinase B: identification of a convergence point for opposing effects of insulin and amino-acid deficiency on protein translation. Biochemical Journal 344, 427-431.

O'Connor PM, Bush JA, Suryawan A, Nguyen HV \& Davis TA (2003a) Insulin and amino acids independently stimulate skeletal muscle protein synthesis in neonatal pigs. American Journal of Physiology 284, E110-E119.

O'Connor PM, Kimball SR, Suryawan A, Bush JA, Nguyen HV, Jefferson LS \& Davis T (2003b) Regulation of translation initiation by insulin and amino acids in skeletal muscle of neonatal pigs. American Journal of Physiology 285, E40-E53.

O'Connor PM, Kimball SR, Suryawan A, Bush JA, Nguyen HV, Jefferson LS \& Davis TA (2004) Regulation of neonatal liver protein synthesis by insulin and amino acids in pigs. American Journal of Physiology 286, E994-E1003.

Ohanna M, Sobering AK, Lapointe T, Lorenzo L, Praud C, Petroulakis E, Sonenberg N, Kelly PA, Sotiropoulos A \& Pende M (2005) Atrophy of S6K1(-/-) skeletal muscle cells reveals distinct mTOR effectors for cell cycle and size control. Nature Cell Biology 7, 286-294.

Oldham S \& Hafen E (2003) Insulin/IGF and target of rapamycin signaling: a TOR de force in growth control. Trends in Cell Biology 13, 79-85.

Ozes ON, Akca H, Mayo LD, Gustin JA, Maehema T, Dixon JE \& Donner DB (2001) A phosphatidylinositol 3-kinase/Akt/mTOR pathway mediates and PTEN antagonizes tumor necrosis factor inhibition of insulin signalling through insulin receptor substrate-1. Proceedings of the National Academy of Sciences USA 98, 4640-4645.

Pain VM (1996) Initiation of protein synthesis in eukaryotic cells. European Journal of Biochemistry 236, 747-771.

Patti ME, Sun XJ, Bruening JC, Araki E, Lipes MA, White MF \& Kahn CR (1995) 4PS/insulin receptor substrate (IRS)-2 is the alternative substrate of the insulin receptor in IRS-1-deficient mice. Journal of Biological Chemistry 270, 24670-24673.

Pelicci G, Lanfrancone L, Grignani F, McGlade J, Cavallo F, Forni G, Nicoletti I, Grignani F, Pawson T \& Pelicci PG (1992) A novel transforming protein (SHC) with an $\mathrm{SH} 2$ domain is implicated in mitogenic signal transduction. Cell 70, 93-104.

Pende M, Um SH, Mieulet V, Sticker M, Goss VL, Mestan J, Mueller M, Fumagalli S, Kozma SC \& Thomas G (2004) S6K1(-/-)/S6K2(-/-) mice exhibit perinatal lethality and rapamycin-sensitive $5^{\prime}$-terminal oligopyrimidine mRNA translation and reveal a mitogen-activated protein kinase-dependent S6 kinase pathway. Molecular and Cellular Biology 24, 3112-3124.

Prod'homme M, Balage M, Debras E, Farges MC, Kimball S, Jefferson L \& Grizard J (2005) Differential effects of insulin and dietary amino acids on muscle protein synthesis in adult and old rats. Journal of Physiology 563, 235-248.

Prod'homme M, Rieu I, Balage M, Dardevet D \& Grizard J (2004) Insulin and amino acids both strongly participate to the regulation of protein metabolism. Current Opinion in Clinical Nutrition and Metabolic Care 7, 71-77.

Proud CG (2002) Regulation of mammalian translation factors by nutrients. European Journal of Biochemistry 269, 5338-5349.

Proud CG (2004) mTOR-mediiated regulation of translation factors by amino acids. Biochemical and Biophysical Research Communications 313, 429-436.

Pullen N \& Thomas G (1997) The modular phosphorylation and activation of p70s6k. FEBS Letters 410, 78-82.

Reynolds TH IV, Bodine SC \& Lawrence JC Jr (2002) Control of Ser2448 phosphorylation in the mammalian target of rapamycin by insulin and skeletal muscle load. Journal of Biological Chemistry 277, 17657-17662.

Rohde J, Heitman J \& Cardenas ME (2001) The TOR kinases link nutrient sensing to cell growth. Journal of Biological Chemistry 276, 9583-9586.

Romanelli A, Martin KA, Toker A \& Blenis J (1999) p70 S6 kinase is regulated by protein kinase $\mathrm{C} \zeta$ and participates in a phosphoinositide 3-kinase-regulated signalling complex. Molecular and Cellular Biology 19, 2921-2928.

Rommel C, Bodine SC, Clarke BA, Rossman R, Nunez L, Stitt TN, Yancopoulos GD \& Glass DJ (2001) Mediation of IGF-1induced skeletal myotube hypertrophy by $\mathrm{PI}(3) \mathrm{K} / \mathrm{Akt} / \mathrm{mTOR}$ and $\mathrm{PI}(3) \mathrm{K} / \mathrm{Akt} / \mathrm{GSK} 3$ pathways. Nature Cell Biology 3, 1009-1013.

Sarbassov DD, Ali SM, Kim DH, Guertin DA, Latek RR, Erdjument-Bromage H, Tempst P \& Sabatini DM (2004) Rictor, a novel binding partner of mTOR, defines a rapamycininsensitive and raptor-independent pathway that regulates the cytoskeleton. Current Biology 14, 1296-1302.

Sarbassov DD, Guertin DA, Ali SM \& Sabatini DM (2005) Phosphorylation and regulation of Akt/PKB by the rictor-mTOR complex. Science 307, 1098-1101.

Sekulic A, Hudson CC, Homme JL, Yin P, Otterness DM, Karnitz LM \& Abraham RT (2000) A direct linkage between the phosphoinositide 3-kinase-AKT signaling pathway and the mammalian target of rapamycin in mitogen-stimulated and transformed cells. Cancer Research 60, 3504-3513. 
Shepherd PR, Withers DJ \& Siddle K (1998) Phosphoinositide 3-kinase, the key switch mechanism in insulin signalling. Biochemical Journal 333, 471-490.

Simon J (1989) Chicken as a useful species for the comprehension of insulin action. Critical Reviews in Poultry Biology 2, $121-148$.

Simon J, Derouet M \& Gespach C (2000) An anti-insulin serum, but not a glucagon antagonist, alters glycemia in fed chickens. Hormone and Metabolic Research 32, 139-141.

Simon J, Freychet P \& Rosselin G (1977) A study of insulin binding sites in the chicken tissues. Diabetologia 13, 219-228.

Simon J \& Leroith D (1986) Insulin receptors of chicken liver and brain. Characterization of alpha and beta subunit properties. European Journal of Biochemistry 158, 125-132.

Sinaud S, Balage M, Bayle G, Dardevet D, Vary TC, Kimball SR, Jefferson LS \& Grizard J (1999) Diazoxide-induced insulin deficiency greatly reduced muscle protein synthesis in rats: involvement of eIF4E. American Journal of Physiology 276, E50-E61.

Skolnik EY, Batzer A, Li N, Lee CH, Lowenstein E, Mohammadi M, Margolis B \& Schlessinger J (1993) The function of GRB2 in linking the insulin receptor to Ras signaling pathways. Science 260, 1953-1955.

Stocker H, Radimerski T, Schindelholz B, Wittwer F, Belawat P, Daram P, Breuer S, Thomas G \& Hafen E (2003) Rheb is an essential regulator of $\mathrm{S} 6 \mathrm{~K}$ in controlling cell growth in Drosophila. Nature Cell Biology 5, 559-565.

Sun XJ, Rothenberg P, Kahn CR, Backer JM, Araki E, Wilden PA, Cahill DA, Goldstein BJ \& White MF (1991) Structure of the insulin receptor substrate IRS-1 defines a unique signal transduction protein. Nature 352, 73-77.

Taouis M, Derouet M, Caffin JP, Chavanieu A \& Simon J (1993) Insulin receptor and insulin sensitivity in a chicken hepatoma cell line. Molecular and Cellular Endocrinology 96, 113-123.

Taouis M, Dupont J, Gillet A, Derouet M \& Simon J (1998) Insulin receptor substrate 1 antisense expression in an hepatoma cell line reduces cell proliferation and induces overexpression of the Src homology 2 domain and collagen protein (SHC). Molecular and Cellular Endocrinology 137, 177-186.

Taouis M, Taylor SI \& Reitman M (1996) Cloning of the chicken insulin receptor substrate 1 gene. Gene 178, 51-55.

Tesseraud S (1995) Métabolisme protéique chez le poulet en croissance. Effet des protéines alimentaires (Protein metabolism in the growing chicken. Effect of food proteins). INRA Productions Animales 8, 197-212.

Tesseraud S, Bigot K \& Taouis M (2003) Amino acid availability regulates $\mathrm{S} 6 \mathrm{~K} 1$ and protein synthesis in avian insulin-intensive QM7 myoblasts. FEBS Letters 540, 176-180.

Tokudome T, Horio T, Yoshihara F, Suga S, Kawano Y, Kohno M \& Kangawa K (2004) Direct effects of high glucose and insulin on protein synthesis in cultured cardiac myocytes and DNA and collagen synthesis in cardiac fibroblasts. Metabolism 53, $710-715$.

Tremblay F \& Marette A (2001) Amino acid and insulin signalling via the mTOR/p70 S6 kinase pathway. A negative feedback mechanism leading to insulin resistance in skeletal muscle cells. Journal of Biological Chemistry 276, 38052-38060.

Ueki K, Yamamoto-Honda R, Kaburagi Y, Yamauchi T, Tobe K, Burgering BM, Coffer PJ, Komuro I, Akanuma Y, Yazaki Y \& Kadowaki T (1998) Potential role of protein kinase B in insulininduced glucose transport, glycogen synthesis, and protein synthesis. Journal of Biological Chemistry 273, 5315-5322.

Um SH, Frigerio F, Watanabe M, Picard F, Joaquin M, Sticker M, Fumagalli S, Allegrini PR, Kozma SC, Auwerx J \& Thomas G (2004) Absence of S6K1 protects against age- and diet-induced obesity while enhancing insulin sensitivity. Nature 431, 200-205.

Vaudin P, Dupont J, Duchene S, Audouin E, Crochet S, Berri C \& Tesseraud S (2006) Phosphatase PTEN in chicken muscle is regulated during ontogenesis. Domesitc Animal Endocrinology (In the press).

Wellbrock C, Karasarides M \& Marais R (2004) The RAF proteins take centre stage. Nature Reviews. Molecular Cell Biology 5, $875-885$.

Weng LP, Smith WM, Brown JL \& Eng C (2001) PTEN inhibits insulin-stimulated MEK/MAPK activation and cell growth by blocking IRS-1 phosphorylation and IRS-1/Grb-2/Sos complex formation in a breast cancer model. Human Molecular Genetics 10, 605-616.

Weng QP, Kozlowski M, Belham C, Zhang A, Comb MJ \& Avruch J (1998) Regulation of the p70 S6 kinase by phosphorylation in vivo. Analysis using site-specific antiphosphopeptide antibodies. Journal of Biological Chemistry 273, 16621-16629.

Whiteman EL, Cho H \& Birnbaum MJ (2002) Role of Akt/protein kinase $\mathrm{B}$ in metabolism. Trends in Endocrinology and Metabolism 13, 444-451.

Wijesekara N, Konrad D, Eweida M, Jefferies C, Liadis N, Giacca A, Crackower M, Suzuki A, Mak TW, Kahn CR, Klip A \& Woo M (2005) Muscle-specific Pten deletion protects against insulin resistance and diabetes. Molecular and Cellular Biology 25, $1135-1145$.

Yamada KM \& Araki M (2001) Tumor suppressor PTEN: modulator of cell signaling, growth, migration and apoptosis. Journal of Cell Science 114, 2375-2382.

Yoshizawa F (2004) Regulation of protein synthesis by branchedchain amino acids in vivo. Biochemical and Biophysical Research Communications 313, 417-422.

Zick Y (2004) Uncoupling insulin signalling by serine/threonine phosphorylation: a molecular basis for insulin resistance. Biochemical Society Transactions 32, 812-816. 